\title{
Eokines: Synthesis, Storage and Release from Human Eosinophils
}

\author{
P Lacy, R Moqbel
}

Pulmonary Research Group, Department of Medicine, 574 Heritage Medical Research Centre, University of Alberta, Edmonton, AB T6G 2S2, Canada

Eosinophils are prominent inflammatory cells in asthma and other allergic disorders, as well as in helminthic parasite infections. Recently, eosinophils have been reported to synthesize and store a range of regulatory proteins within their secretory granules (eokines). Eokines comprise a group of cytokines, chemokines, and growth factors which are elaborated by eosinophils. These proteins, and the messages which encode them, appear to be identical to those produced by lymphocytes and other tissues. Interestingly, immunoreactivity to many of these eokines has been found to co-localize to the eosinophil's secretory granules. In this review, we have discussed the repertoire of 18 eokines so far identified in eosinophils, and focused on four of these, namely, interleukin-2 (IL-2), IL-4, granulocyte/macrophage colonystimulating factor (GM-CSF), and RANTES. These four eokines co-localize to the crystalloid granules in eosinophils, as shown in studies using subcellular fractionation and immunogold labeling in electron microscopy. During stimulation by physiological triggers, for example, with serum-coated particles, eosinophils release these mediators into the surrounding supernatant. In addition, eokines are likely to be synthesized within eosinophils rather than taken up by endocytosis, as show in detection of mRNA for each of these proteins using in situ hybridization, RT-PCR, and in the case of RANTES, in situ RT-PCR. Eokines synthesis and release from eosinophils challenges the commonly held notion that these cells act downstream of key elements in immune system, and indicate that they may instead belong to the afferent arm of immunity.

Key words: cytokines - chemokines - interleukin-2 - interleukin-4 - granulocyte/macrophage-colony-stimulating factor - RANTES

Since its early discovery, it has been difficult to describe clearly defined immunological roles for the eosinophil. To compound this problem, eosinophils have been frequently overlooked in their potential pathophysiological functions in studies of immunology and human disease. The eosinophil was originally believed to mediate an immunomodulatory function in acute phases of anaphylaxis by the action of released histaminase, which was thought to reduce histamine-induced inflammation brought on by mast cell degranulation. Later it was realized that eosinophils were critically important in helminthic parasite infections, although it was still uncertain as to whether they were engaged in self-protection or parasite destruction. In the last few years, workers in the field of eosinophil research have witnessed a dramatic transformation in the understanding of the pathophysiological function of eosinophils. It has become apparent that eosinophils may be capable of

\footnotetext{
${ }^{+}$Correponding author. Fax: +403-492.5329. E-mail: redwan.moqbel@ualberta.ca Received 3 September 1997 Accepted 30 September 1997
}

direct proinflammatory reactions in atopic disease, through the release of toxic lipid and granule mediators following stimulation. Eosinophil-derived mediators can have potent effects on surrounding tissues in both in vitro and in vivo studies, including stimulation of further degranulation from mast cells and neighbouring eosinophils, deposition of cytotoxic granule major basic protein (MBP) in lung tissue, and epithelial desquamation. These events feature strongly in atopic asthma, and have led to speculation that the eosinophil may be a primary cell type involved in the initiation of atopic disease and its exacerbations.

Eosinophils have a newly discovered capacity to express and store a range of regulatory proteins in their secretory granules (eokines). These mediators are cytokines, chemokines, and growth factors. The potential ability of the eosinophil to produce these molecules has led to a fundamental reappraisal of the role of this cell in regulation of inflammatory reactions in atopic and parasitic diseases, and may hopefully shed more light on the function of eosinophils in immunity. The purpose of this review is to examine the repertoire of eokines so far identified in eosinophils, and to focus on the potential contribution of some of these 
eosinophil-derived molecules towards the pathology of eosinophil-related atopic inflammation and disease.

\section{CYTOKINES, CHEMOKINES, AND GROWTH FAC- TORS IDENTIFIED IN HUMAN EOSINOPHILS}

Cytokines, chemokines, and growth factors are rapidly synthesized in high concentrations upon stimulation of a wide range of tissues, including $\mathrm{T}$ cells, B cells, and other mononuclear cells. Granulocytic cells, including eosinophils, are also capable of synthesizing many of these inflammatory and chemotactic mediators. Following the discovery by del Pozo and co-workers in 1990 that murine peritoneal eosinophils express IL-1 $\alpha$ mRNA and release its translated product following stimulation by LPS, it has since been realized that not only are eosinophils capable of producing these regulatory mediators, but they also store many of them, often in association with their characteristic crystalloid secretory granules. Some of these stored cytokines can be released upon in vitro activation of eosinophils, suggesting that secretion of cytokines may occur by regulated exocytosis (as opposed to constitutive exocytosis). The Table shows cytokines, chemokines, and growth factors so far described in human eosinophils. The detection methods used for these mediators include immunocytochemistry, in situ hybridization, and in situ PCR on tissue sections, and ELISA assays on cells and supernatants.

\section{SYNTHESIS AND STORAGE OF EOKINES}

Eosinophils have so far been shown to express message and/or protein for at least 18 different cytokines, chemokines, and growth factors (Table). Since the quantity of these exceeds the scope of this review, we will focus on the possible mechanisms of synthesis, storage, and release of a selected group of eokines.

Eosinophils have been demonstrated to store interleukin-2 (IL-2), IL-4, GM-CSF, and possibly RANTES in their crystalloid granules (Figs 1, 2). The crystalloid granule, unique to these cells, is a membrane-bound organelle composed of a crystalline core (internum) which is almost entirely composed of the highly charged cationic major basic protein (MBP). Surrounding this core is the matrix, a liquid phase which contains concentrated amounts of three further cationic proteins among a plethora of other granule enzymes and proteins. These are eosinophil cationic protein (ECP), eosinophil-derived neurotoxin (EDN), and eosinophil peroxidase (EPO). Many chemokines, cytokines, and growth factors co-localize to the matrix of the granules, although some have been reported to associate with the core.

Interleukin-2 - IL-2 is known to be an essential growth factor for $\mathrm{T}$ cells, and eosinophils respond by chemotaxis to this cytokine (Rand et al. 1991). An average of $6.8 \pm 0.4 \%$ of freshly isolated, unstimulated peripheral blood eosinophils from

TABLE

Human eosinophil-derived cytokines, chemokine, and growth factors

\begin{tabular}{|c|c|c|c|c|c|}
\hline $\begin{array}{l}\text { Mediator detected } \\
\text { in human } \\
\text { eosinophils }\end{array}$ & $\begin{array}{l}\text { Molecule } \\
\text { detected }\end{array}$ & $\begin{array}{l}\text { Quantity of } \\
\text { protein } \\
\text { stored (per } \\
10^{6} \text { cells) }\end{array}$ & Release factors & $\begin{array}{l}\text { Intracellular } \\
\text { localization of } \\
\text { stored protein }\end{array}$ & Reference \\
\hline
\end{tabular}

\begin{tabular}{|c|c|c|c|c|c|}
\hline Interleukin-1 $\alpha$ & $\begin{array}{l}\text { mRNA } \\
\text { protein }\end{array}$ & - & PMA & - & Weller et al. (1993) \\
\hline Interleukin-2 & $\begin{array}{l}\text { mRNA } \\
\text { protein }\end{array}$ & $6 \pm 2 \mathrm{pg}$ & $\begin{array}{l}\text { Serum-coated } \\
\text { particles, PHA }\end{array}$ & $\begin{array}{l}\text { Crystalloid } \\
\text { granules (core) }\end{array}$ & $\begin{array}{l}\text { Levi-Schaffer et al. (1996) } \\
\text { Bossé et al. (1996) }\end{array}$ \\
\hline Interleukin-3 & $\begin{array}{l}\text { mRNA } \\
\text { protein }\end{array}$ & - & $\begin{array}{l}\text { Ionomycin } \\
\text { IFN } \gamma\end{array}$ & - & $\begin{array}{l}\text { Kita et al. (1991) } \\
\text { Fujisawa et al. (1994) }\end{array}$ \\
\hline Interleukin-4 & $\begin{array}{l}\text { mRNA } \\
\text { protein }\end{array}$ & $108 \pm 20 \mathrm{pg}$ & $\begin{array}{l}\text { Immune } \\
\text { complexes } \\
\text { Serum-coated } \\
\text { particles }\end{array}$ & $\begin{array}{l}\text { Crystalloid } \\
\text { granules (core) }\end{array}$ & $\begin{array}{l}\text { Nonaka et al. (1995) } \\
\text { Moqbel et al. (1995) } \\
\text { Möller et al. (1996a) } \\
\text { Nakajima et al. (1996) }\end{array}$ \\
\hline Interleukin-5 & $\begin{array}{l}\text { mRNA } \\
\text { protein }\end{array}$ & - & $\begin{array}{l}\text { Immune } \\
\text { complexes }\end{array}$ & $\begin{array}{l}\text { Crystalloid } \\
\text { granules } \\
\text { (core/matrix?) }\end{array}$ & $\begin{array}{l}\text { Desreumaux et al. (1992) } \\
\text { Broide et al. (1992) } \\
\text { Desreumaux et al. (1993) } \\
\text { Dubucquoi et al. (1994) } \\
\text { Möller et al. (1996b) }\end{array}$ \\
\hline Interleukin-6 & $\begin{array}{l}\text { mRNA } \\
\text { protein }\end{array}$ & - & $\mathrm{IFN} \gamma$ & - & $\begin{array}{l}\text { Hamid et al. (1992) } \\
\text { Melani et al. (1993) }\end{array}$ \\
\hline
\end{tabular}




\begin{tabular}{|c|c|c|c|c|c|}
\hline $\begin{array}{l}\text { Mediator detected } \\
\text { in human } \\
\text { eosinophils }\end{array}$ & $\begin{array}{l}\text { Molecule } \\
\text { detected }\end{array}$ & $\begin{array}{l}\text { Quantity of } \\
\text { protein } \\
\text { stored (per } \\
10^{6} \text { cells) }\end{array}$ & Release factors & $\begin{array}{l}\text { Intracellular } \\
\text { localization of } \\
\text { stored protein }\end{array}$ & Reference \\
\hline Interleukin-10 & $\begin{array}{l}\text { mRNA } \\
\text { protein }\end{array}$ & - & $\begin{array}{l}\text { [Constitutively } \\
\text { released] }\end{array}$ & - & Nakajima et al. (1996) \\
\hline Interleukin-16 & $\begin{array}{l}\text { mRNA } \\
\text { protein }\end{array}$ & - & $\begin{array}{l}\text { [Constitutively } \\
\text { released] }\end{array}$ & - & Lim et al. (1996) \\
\hline $\begin{array}{l}\text { Interferon- } \gamma \\
(\mathrm{IFN} \gamma)\end{array}$ & mRNA & - & - & - & Lamkhioued et al. (1996) \\
\hline $\begin{array}{l}\text { Tumor necrosis } \\
\text { factor- } \alpha(\text { TNF- } \alpha)\end{array}$ & $\begin{array}{l}\text { mRNA } \\
\text { protein }\end{array}$ & - & $\begin{array}{l}\text { Immune } \\
\text { complexes } \\
\text { TNF } \alpha \text {, LPS }\end{array}$ & - & $\begin{array}{l}\text { Beil et al. (1993) } \\
\text { Costa et al. (1993) } \\
\text { Tan et al. (1993) } \\
\text { Takanaski et al. (1994) } \\
\text { Nakajima et al. (1996) }\end{array}$ \\
\hline $\begin{array}{l}\text { Granulocyte/ } \\
\text { Macrophage } \\
\text { Colony-Stimulating } \\
\text { Factor (GM-CSF) }\end{array}$ & $\begin{array}{l}\text { mRNA } \\
\text { protein }\end{array}$ & $15.1 \pm 0.3 \mathrm{pg}$ & $\begin{array}{l}\text { Ionomycin } \\
\text { LPS, IFN } \gamma \text {, } \\
\text { Immobilized } \\
\text { fibronectin, } \\
\text { anti-CD40, } \\
\text { anti-CD9 }\end{array}$ & $\begin{array}{l}\text { Crystalloid } \\
\text { granules } \\
\text { (core) }\end{array}$ & $\begin{array}{l}\text { Moqbel et al. (1991) } \\
\text { Kita et al. (1991) } \\
\text { Ohno et al. (1991) } \\
\text { Broide et al. (1992) } \\
\text { Anwar et al. (1993) } \\
\text { Takanaski et al. (1994) } \\
\text { Levi-Schaffer et al. (1995) } \\
\text { Ohkawara et al. (1996) } \\
\text { Kim et al. (1997) }\end{array}$ \\
\hline \multicolumn{6}{|l|}{ B. Chemokines } \\
\hline Interleukin-8 & $\begin{array}{l}\text { mRNA } \\
\text { protein }\end{array}$ & - & $\begin{array}{l}\text { C5a, fMLP } \\
\text { GM-CSF - } \\
\text { RANTES or } \\
\text { PAF, Immune } \\
\text { complexes } \\
\text { TNF } \alpha, \text { LPS }\end{array}$ & - & $\begin{array}{l}\text { Braun et al. (1993) } \\
\text { Takanaski et al. (1994) } \\
\text { Miyamasu et al. (1995) } \\
\text { Yousefi et al. (1995) } \\
\text { Nakajima et al. (1996) }\end{array}$ \\
\hline $\begin{array}{l}\text { Macrophage } \\
\text { Inflammatory } \\
\text { Protein-1 } \alpha \text { (MIP-1 } \alpha)\end{array}$ & $\begin{array}{l}\text { mRNA } \\
\text { protein }\end{array}$ & - & - & - & Costa et al. (1993) \\
\hline RANTES & $\begin{array}{l}\text { mRNA } \\
\text { protein }\end{array}$ & $7.0 \pm 0.5 \mathrm{ng}$ & $\begin{array}{l}\text { Serum-coated } \\
\text { particles, IFN } \gamma\end{array}$ & - & Ying et al. (1996) \\
\hline \multicolumn{6}{|l|}{ C. Growth Factors } \\
\hline $\begin{array}{l}\text { Transforming } \\
\text { Growth Factor- } \alpha \\
(\text { TGF } \alpha)\end{array}$ & $\begin{array}{l}\text { mRNA } \\
\text { protein }\end{array}$ & - & - & - & $\begin{array}{l}\text { Wong et al. (1990) } \\
\text { Elovic et al. (1994) }\end{array}$ \\
\hline $\begin{array}{l}\text { Transforming } \\
\text { Growth Factor- } \beta 1 \\
\text { (TGF- } \beta 1 \text { ) }\end{array}$ & $\begin{array}{l}\text { mRNA } \\
\text { protein }\end{array}$ & - & - & - & $\begin{array}{l}\text { Wong et al. (1991) } \\
\text { Ohno et al. (1992) } \\
\text { Kadin et al. (1993) } \\
\text { Ohno et al. (1996) }\end{array}$ \\
\hline $\begin{array}{l}\text { Platelet-Derived } \\
\text { Growth Factor, } \\
\text { B chain (PDGF-B) }\end{array}$ & mRNA & - & - & - & Ohno et al. (1995) \\
\hline $\begin{array}{l}\text { Heparin-Binding } \\
\text { Epidermal Growth } \\
\text { Factor-Like } \\
\text { Binding Protein } \\
\text { (HB-EGF-LBP) }\end{array}$ & mRNA & - & - & - & Powell et al. (1993) \\
\hline
\end{tabular}

- : not yet determined. 


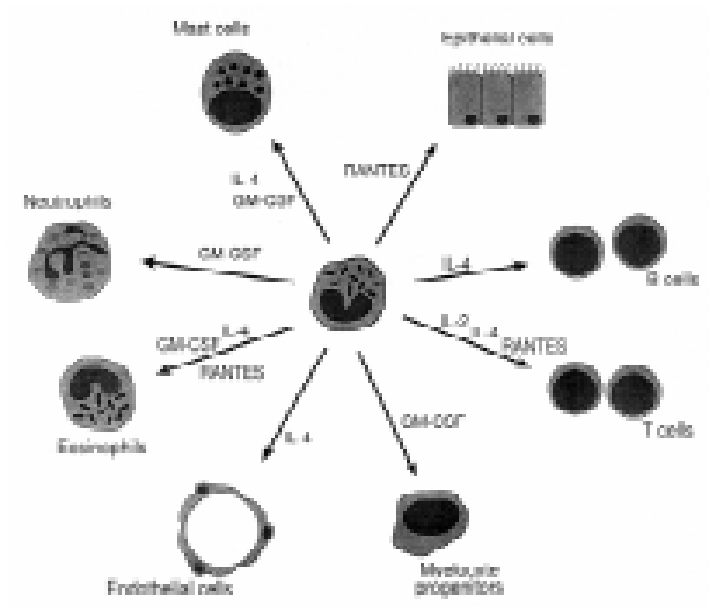

Fig. 1: potential targets for eosinophil-derived IL-2, IL-4, GMCSF, and RANTES.

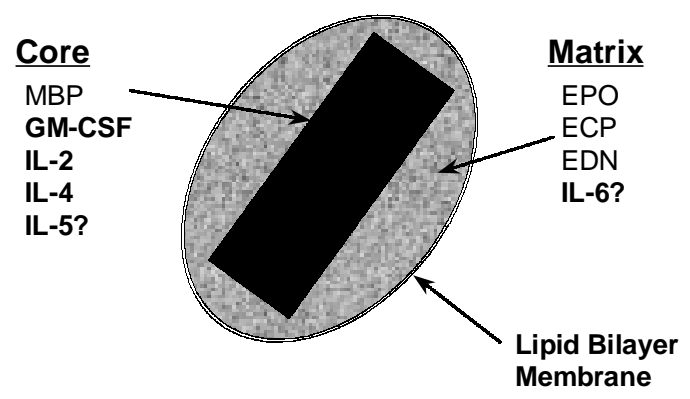

Fig. 2: localization of eosinophil-derived cytokines to the crystalloid granule.

atopic asthmatics exhibited granular IL-2 staining using immunocytochemistry (Levi-Schaffer et al. 1996). The percentage of IL-2 ${ }^{+}$blood eosinophils was elevated to $36 \pm 8 \%$ in severe atopic asthmatics (Bossé et al. 1996). When cells were subjected to in situ PCR followed by in situ hybridization, IL-2 mRNA could be detected which was increased during incubation with GM-CSF and/or A23187. Freshly prepared, disrupted, unstimulated eosinophils store an average of $6 \pm 2 \mathrm{pg} / 10^{6}$ cells of IL-2 as measured by ELISA, while eosinophils incubated with serum-coated Sephadex beads increased their content of IL-2 to $26 \pm 7 \mathrm{pg}$ of IL-2/10 6 cells (LeviSchaffer et al. 1996). Furthermore, using subcellular fractionation, IL-2 co-eluted with granule enzyme marker activities (MBP, ECP, EPO, arylsulfatase B, and $\beta$-hexosaminidase). However, as this procedure does not discriminate between core and matrix-associated granule proteins, immunogold labeling with a monoclonal antibody to IL-2 was carried out to determine the precise location of its storage.
Using electron microscopy on labeled sections, immunoreactivity to IL-2 co-localized to the core of secretory granules in freshly prepared unstimulated blood eosinophils. So far, IL-2 has only been identified in peripheral blood eosinophils, and no reports have appeared describing IL-2 immunoreactivity in eosinophils from tissue sections of biopsies obtained from atopic individuals.

A small amount of IL-2 release $\left(2 \pm 1 \mathrm{pg} / 10^{6}\right.$ cells) can be stimulated by incubating serum-coated Sephadex beads with eosinophils freshly isolated from three out of six atopic asthmatic subjects (Levi-Schaffer et al. 1996). The potential physiological effects of eosinophil-derived IL-2 is likely to be of a juxtacrine or autocrine nature. Eosinophils themselves respond to IL-2 by chemotaxis and express the IL-2 receptor (CD25) (Rand et al. 1991). Another possible action of IL-2 released from eosinophils may be induction of $\mathrm{T}$ cell growth and activation at a local tissue level, which may act in conjunction with eosinophil-derived IL-4 to drive the response towards a Th2 phenotype. However, the bioactivity of eosinophil-derived IL-2 awaits further study.

Interleukin-4 - IL-4 is regarded as a critical cytokine in initiation and maintenance of the allergic phenotype, and its effects include switching of $\mathrm{T}$ cells to the Th2 subset as well as B cells to the IgE-producing phenotype (Del Prete et al. 1988, Mosmann \& Coffman 1989). It also exhibits chemotactic activity towards eosinophils (Dubois et al. 1994). By a combination of RT-PCR and Southern blot analysis of reverse-transcribed eosinophil mRNA, IL-4 mRNA has been detected in highly purified blood eosinophils from atopic asthmatics (Moqbel et al. 1995). An average of $22 \pm 5 \%$ of these cells were found to be positive for IL-4 immunoreactivity using immunocytochemical staining, which was granular in appearance. Measurement of IL-4 by ELISA assay on lysed, unstimulated eosinophils yielded an average of 108 $\pm 20 \mathrm{pg} / 10^{6}$ cells of IL-4 inside the cells. Although the number of $\mathrm{IL}-4^{+}$eosinophils in cytospins of bronchoalveolar lavage (BAL) cells from atopic asthmatics was not significantly different from those of nonatopic normal controls, the majority of eosinophils infiltrating allergen-induced cutaneous late-phase (6-hr) reactions were immunoreactive for IL-4 $(84 \pm 4 \%)$. The work of Nonaka and colleagues (1995) has shown that while IL-4 ${ }^{+}$ eosinophils could not be detected in the bronchial mucosa of nonasthmatics, some IL- $4^{+}$eosinophils could be detected in both diluent-challenged and allergen-challenged tissues of mild atopic asthmatics. Furthermore, immunostained sections of nasal polyp tissues showed that as many as $44 \%$ of eosinophils were positive for IL-4. Highly puri- 
fied peripheral blood eosinophils from normal subjects constitutively express IL-4 mRNA and its product in the absence of external stimuli, although no released IL-4 protein could be detected in supernatants even in the presence of strong physiological stimuli (TNF $\alpha$ and/or immobilized secretory IgA; Nakajima et al. 1996). Interestingly, this study showed that exogenous IL-5 enhanced levels of stored IL-4 in purified eosinophils from normal subjects. In immunogold studies, IL-4 has been localized to the crystalloid core compartment of the secretory granules in eosinophils from peripheral blood (Moqbel et al. 1995) and bronchial biopsies of atopic asthmatics (Möller et al. 1996a). These reports have extended the observation of IL$4^{+}$eosinophils in peripheral blood to tissue eosinophils from atopic subjects, and suggest that IL4 is synthesized in vivo by eosinophils as a part of their pathophysiological function.

By incubation of blood eosinophils for $45 \mathrm{~min}$ with serum-coated Sephadex beads in vitro, IL-4 release could be detected in supernatants at $34 \pm 6$ $\mathrm{pg} / 10^{6}$ cells (Moqbel et al. 1995). Nonaka and coworkers (1995) also demonstrated IL-4 release from eosinophils, detecting $47 \pm 21 \mathrm{pg} / 10^{6}$ cells in supernatants of peripheral blood eosinophils incubated with immobilized secretory IgA for $18 \mathrm{hr}$. These amounts are physiologically relevant, and suggest that eosinophils could potentially provide an initial, rapidly released reservoir of IL-4 for switching naïve precursor Th cells to the Th2 phenotype in local allergic and inflammatory reactions. In support of this notion, mice infected intraperitoneally with Schistosoma mansoni eggs displayed an early rise in IL-4 which was derived from peritoneal eosinophils, and which was also responsible for the subsequent priming of naïve $\mathrm{T}$ cells in the peritoneum (Sabin et al. 1996). Other potential actions of eosinophil-derived IL-4 include enhancement of local IgE production, upregulation of VCAM-1 receptors on endothelial cells, and local chemotaxis of nearby eosinophils. These interesting scenarios await further investigation to determine the physiological role of eosinophil-derived IL-4.

Granulocyte/Macrophage Colony-Stimulating Factor - Eosinophils have been demonstrated to transcribe message for GM-CSF and store its products within their intracellular secretory granules. GM-CSF is a maturation and growth factor for myeloid progenitors (including eosinophils) and is also involved in priming, activation, and prolongation of the survival of mature eosinophils. In peripheral blood eosinophils from atopic asthmatics, GM-CSF mRNA was found to be expressed and upregulated in response to IFN $\gamma$ or A23187 using in situ hybridization (Moqbel et al. 1991). Co-localization of GM-CSF mRNA to eosinophils was achieved by a combination of in situ hybridization and staining with chromotrope 2R or EG2 immunoreactivity. Activated eosinophils were also observed to display specific immunoreactivity with an anti-GM-CSF monoclonal antibody. The transcript for GM-CSF has also been detected in normal peripheral blood eosinophils (Nakajima et al. 1996). In tissue sections, GM-CSF mRNA has been detected in eosinophils in association with nasal polyposis (Ohno et al. 1991), in which approximately $30 \%$ of infiltrating eosinophils expressed this transcript. Eosinophils staining positive for GM-CSF mRNA have also been detected in BAL cells obtained from asthmatic subjects after endobronchial allergen challenge (Broide et al. 1992). In unstimulated eosinophils from atopic asthmatic subjects, the mean concentration of stored GM-CSF was $15.1 \pm 0.3 \mathrm{pg} / 10^{6}$ cells (LeviSchaffer et al. 1995). Following subcellular fractionation of unstimulated eosinophils across a linear gradient, GM-CSF was found to co-elute almost exclusively with marker granule proteins and enzymes. Immunogold staining with anti-GM-CSF showed preferential localization of gold particles with the cores of eosinophil secretory granules, suggesting that eosinophil GM-CSF is stored as a preformed mediator rather than being immediately released after de novo synthesis.

GM-CSF can be released from peripheral blood eosinophils during in vitro incubation of cells with ionomycin or LPS (Kita et al. 1991, Takanaski et al. 1994). Ionomycin-induced release of GM-CSF resulted in the release of $45 \pm 20 \mathrm{pg} / 10^{6}$ cells in supernatants of cultured eosinophils (Kita et al. 1991), while LPS induced the release of $23 \pm 8 \mathrm{pg} / \mathrm{mL}$ of GM-CSF from $5 \times 10^{5}$ freshly isolated peripheral blood eosinophils (Takanaski et al. 1994). LPS failed to stimulate significant GM-CSF release from a maximal number of potentially contaminating mononuclear cells or neutrophils, demonstrating that the LPS-induced release of GM-CSF is exclusively from eosinophils in these preparations. The significance of GM-CSF synthesis and release from eosinophils is that this cytokine may act in an autocrine and/or paracrine manner to prime eosinophils and enhance their survival in vivo. Priming of eosinophils would lead to enhanced exocytosis of eosinophil granule proteins, which mediate a number of inflammatory actions and tissue injury. In this manner, eosinophil-derived GM-CSF may prolong the allergic late phase response in which eosinophils are continually activated in a self-exacerbating cycle of inflammation.

RANTES - Eosinophils have also been shown to be capable of synthesizing and storing the potent CC chemokine RANTES. RANTES is chemotactic for eosinophils, basophils, monocytes/mac- 
rophages, $\mathrm{CD}^{+} / \mathrm{CD} 45 \mathrm{RO}^{+}$memory $\mathrm{T}$ cells, and mast cells, with maximal potency for eosinophils and memory T cells (Schall et al. 1990, Kameyoshi et al. 1992, Baggiolini \& Dahinden 1994, Taub et al. 1995). Highly purified peripheral blood eosinophils from atopic asthmatics have been shown to express mRNA for RANTES by RT-PCR (Ying et al. 1996), which has been confirmed by others (Lim et al. 1996). The presence of RANTES transcript was detected by in situ hybridization, and 4$17 \%$ of blood eosinophils were found to be positive for RANTES mRNA, which increased to 22$30 \%$ following in vitro stimulation with IFN $\gamma$ (1000 U/ml for $16 \mathrm{hr}$ ) (Ying et al. 1996). Immunoreactivity to RANTES was detected in 4-13\% of unstimulated cells, consistent with translation of mRNA for RANTES. Stimulation of eosinophils with IFN $\gamma$ also enhanced the percentage of cells expressing RANTES protein to $11-20 \%$. Incubation of eosinophils with ionomycin did not increase the percentage of cells expressing RANTES mRNA; however, it did increase the percentage of cells positive for RANTES immunoreactivity (to 6-21\%). In eosinophils from normal, healthy subjects, RANTES mRNA was upregulated following $3 \mathrm{hr}$ of stimulation with immobilized immunoglobulins or TNF $\alpha$ (Nakajima et al. 1996). The capacity of human eosinophils to synthesize and translate mRNA encoding RANTES in association with allergic inflammation has also been demonstrated in allergen-induced late-phase cutaneous reactions in atopic subjects (Ying et al. 1996). Unstimulated blood eosinophils from atopic individuals have approximately $7.0 \pm 0.5 \mathrm{ng} / 10^{6}$ cells of RANTES stored inside them as determined by ELISA. It has not yet been established where RANTES is stored within eosinophils, but preliminary data suggest that it may be localized to the small granules.

The release of RANTES may be evoked by serum-coated Sephadex beads from purified blood eosinophils. An average of $1.7 \pm 0.2 \mathrm{ng} / 10^{6}$ cells of RANTES was released into supernatants of in vitrostimulated eosinophils as detected by ELISA (Ying et al. 1996). The apparently high concentrations of RANTES released in supernatants and from lysed cells is probably artefactual, and likely to be due to a contaminating serum component. Recent experiments in our laboratory using more stringently washed serum-coated surfaces has shown that approximately $150-500 \mathrm{pg} / 10^{6}$ cells of RANTES is usually released under these conditions.

RANTES is the only eokine which has been reported to have biological effects on other cells; eosinophil-derived RANTES has been shown to exhibit chemotactic activity towards other eosinophils in vitro, and this effect was inhibited by a mean of $68 \%$ by a specific anti-RANTES antibody (Ying et al. 1996). The release of RANTES from tissue eosinophils during inflammatory responses may serve as a potent chemotactic signal for other tissue eosinophils, circulating eosinophils, and memory $\mathrm{T}$ cells. It is interesting to note in this context that infiltration of eosinophils and memory $\mathrm{T}$ cells into lung tissues is a prominent feature of human asthma, and may indicate a primary role for RANTES in asthmatic inflammation.

\section{CONCLUSIONS}

The detection of mRNA for each of the eokines described here suggests that eosinophils possess the capacity to synthesize these molecules themselves, rather than endocytosing them from the surrounding milieu. Furthermore, density gradient centrifugation of homogenized unstimulated eosinophils has shown that the buoyant density at which cytokine immunoreactivity sedimented was greater than that of endosomes, suggesting storage of cytokines within the very dense crystalloid granules.

Given that eosinophils are apparently capable of producing so many cytokines, chemokines, and growth factors, it should be remembered that the protein detection methods used so far to analyse eokine expression and storage are all based on antibody recognition. Eosinophils are probably the most difficult cells in the body to analyse with specific antibody binding methods, as they contain highly concentrated pockets of positively charged granule proteins that attach nonspecifically to antibodies. Thus, many of the protein detection results so far reported for eosinophils have to be taken on board with a degree of caution, as some of these may represent false positive results due to nonspecific antibody binding. It is therefore mandatory that a carefully chosen blocking regime is employed to prevent false positive results. Similar problems have been encountered with the use of riboprobes, which can adhere to the same granule proteins to give an erroneous positive signal. The use of RT-PCR has helped to overcome uncertainty regarding message expression in eosinophils, but this is also a finicky method due to its inherent randomness in sequence detection and the difficulty of obtaining $100 \%$ pure eosinophil preparations. If cytokine expression is to be fully evaluated in eosinophils, it will be essential to investigate the bioavailability and bioactivity of eokines. The study of eokine bioactivity is currently in progress in several laboratories including our own, and new insights into the functioning of eosinophil-derived molecules will hopefully eventuate in the next few years.

From the findings so far, eosinophils exhibit a remarkable degree of biological versatility and heterogeneity. Stored cytokines in eosinophils may 
serve as a rapidly mobilizable reservoir of inflammatory mediators in allergic reactions association with eosinophils, in contrast to T cells and other cells which do not store these compounds. The expression of these molecules by eosinophils suggest that these cells may play an afferent role in the immune system, since eosinophils can express MHC Class II and present antigen to T cells (Del Pozo et al. 1992, Weller et al. 1993) and produce IL-4 upon activation (Moqbel et al. 1995, Nonaka et al. 1995). It is likely that the actions of many eosinophil-derived cytokines are mediated by putative paracrine, autocrine, or juxtacrine signalling mechanisms, since the quantities of cytokines released are low in comparison to levels achieved by in vitro stimulation of $\mathrm{T}$ cells. However, local release of eokines would suggest that a number of interesting scenarios occur in tissue inflammation. The release of highly concentrated packets of cytokines in close proximity to target cells may result in a cascade of inflammatory responses as part of an amplification process. In this manner, the eosinophil may be involved in amplifying or modulating the local allergic response in asthma, thus contributing to tissue damage, while on the other hand it may promote putative protective immune reactions, as in helminthic infections. At the other end of the spectrum, it is possible that in spite of the circumstantial evidence in favour of a possible effector role for this cell, eosinophil cytokine production may be a redundant process in immune and inflammatory events. However, as mentioned earlier, murine studies of eosinophil-derived IL-4 suggest a role for this mediator in mounting a Th2 response in reaction to helminthic infection (Sabin et al. 1996). This observation awaits further investigations using human tissues.

These findings have brought about exciting times for eosinophil research. The eosinophil is rapidly becoming the focus of attention in atopic disease. There is now a large body of evidence available showing strong clinical correlation between increasing numbers of eosinophils infiltrating lung tissue and severity of disease in asthma. Sadly, the rate of asthma affliction is rising steeply in many countries around the world. As we discover more about the immunobiology of eosinophils, we may hopefully increase the number of ways of treating atopy, and develop new treatment regimes for these clinical conditions.

\section{REFERENCES}

Anwar ARF, Moqbel R, Walsh GM, Kay AB, Wardlaw AJ 1993. Adhesion to fibronectin prolongs eosinophil survival. J Exp Med 177: 839-843.

Baggiolini M, Dahinden CA 1994. CC chemokines in allergic inflammation. Immunol Today 15: 127-133. Beil WJ, Weller PF, Tzizik DM, Galli SJ, Dvorak AM
1993. Ultrastructural immunogold localization of tumor necrosis factor- $\alpha$ to the matrix compartment of eosinophil secondary granules in patients with idiopathic hypereosinophilic syndrome. J Histochem Cytochem 41: 1611-1615.

Bossé M, Audett M, Ferland C, Pelletier G, Chu HW, Dakhama A, Lavigne S, Boulet L-P, Laviolette M 1996. Human eosinophils transcribe and translate mRNA for interleukin-2. Immunology 84: 149-154.

Braun RK, Franchini M, Erard F, Rihs S, de Vries IJM, Blaser K. Hansel TT, Walker C 1993. Human peripheral blood eosinophils produce and release interleukin-8 on stimulation with calcium ionophore. Eur J Immunol 23: 956-960.

Broide DH, Paine M, Firestein G 1992. Eosinophils express interleukin-5 and granulocyte macrophagecolony-stimulating factor mRNA at sites of allergic inflammation. J Clin Invest 90: 1414-1424.

Costa JJ, Matossian K, Resnick MB, Beil WJ, Wong DT, Gordon JR, Dvorak AM, Weller PF, Galli SJ 1993. Human eosinophils can express the cytokines tumor necrosis factor-a and macrophage inflammatory protein-1 $\alpha$. J Clin Invest 91: 2673-2684.

Del Pozo V, De Andres B, Martin , Maruri N, Zubeldia JM, Palomino P, Lahoz, C 1990. Murine eosinophils and IL-1: alpha IL-1 mRNA detection by in situ hybridization. Production and release IL-1 from peritoneal eosinophils. J Immunol 144: 3117 3122.

Del Pozo V, De Andres B, Martin E, Cardaba B, Fernandez JC, Gallardo S, Tramon P, Leyva-Cobian F, Palomino P, Lahoz C 1992. Eosinophil as antigen-presenting cell: activation of $\mathrm{T}$ cell clones and $\mathrm{T}$ cell hybridoma by eosinophils after antigen processing. Eur J Immunol 22: 1919-1925.

Del Prete G, Maggi E, Parronchi P, Chretien I, Tiri A, Macchia D, Ricci M, Banchereau J, De Vries J, Romagnani S 1988. IL-4 is an essential factor for the IgE synthesis induced in vitro by human $\mathrm{T}$ cell clones and their supernatants. J Immunol 140: 4193-4198.

Desreumaux PA, Janin A, Colombel JF, Prin L, Plumas J, Emiliee D, Torpier G, Capron A, Capron M 1992. Interleukin-5 mRNA expression by eosinophils in the intestinal mucosa of patients with coeliac disease. J Exp Med 175: 293-296.

Desreumaux P, Janin A, Dubucquoi S, Copin MC, Torpier G, Capron A, Capron M, Prin L 1993. Synthesis of interleukin-5 by activated eosinophils in patients with eosinophilic heart disease. Blood 82 : 1553-1560.

Dubois GR, Bruijnzeel-Koomen CA, Bruijnzeel PL 1994. IL-4 induces chemotaxis of blood eosinophils from atopic dermatitis patients, but not from normal individuals. J Invest Dermatol 102: 843-846.

Dubucquoi SP, Desreumaux P, Janin A, Klein O, Goldman M, Tavernier J, Capron A, Capron M 1994. Interleukin 5 synthesis by eosinophils: association with granules and immunoglobulin-dependent secretion. J Exp Med 179: 703-708.

Elovic A, Wong DT, Weller PF, Matossian K, Galli SJ 1994. Expression of transforming growth factors- $\alpha$ and $\beta 1$ messenger RNA and product by eosinophils 
in nasal polyps. J Allergy Clin Immunol 93: 864-869.

Fujisawa T, Fukuda S, Atsuta J, Ichimi R, Kamiya H, Sakurai M 1994. Interferon- $\gamma$ induced interleukin-3 release from peripheral blood eosinophils. Intl Arch Allergy Immunol 104 (Suppl. 1): 41-43.

Hamid Q, Barkans J, Abrams JS, Qiu Meng, Sun Ying, Kay AB, Moqbel R 1992. Human eosinophils synthesize and secrete interleukin-6, in vitro. Blood 80 : 1496-1501.

Kadin M, Butmarc J, Elovic A, Wong D 1993. Eosinophils are the major source of transforming growth factor- $\beta 1$ in nodular sclerosing Hodgkin's disease. Am J Pathol 142: 11-16.

Kameyoshi Y, Dorschner A, Mallet AI, Christophers E, Schroder JM 1992. Cytokine RANTES released by thrombin-stimulated platelets is a potent attractant for human eosinophils. J Exp Med 176: 587-592.

Kim JT, Gleich GJ, Kita H 1997. Roles of CD9 molecules in survival and activation of human eosinophils. J Immunol 159: 926-933.

Kita H, Ohnishi T, Okubo Y, Weiler D, Abrams JS, Gleich GJ 1991. GM-CSF and interleukin-3 release from human peripheral blood eosinophils and neutrophils. J Exp Med 174: 743-748.

Lamkhioued B, Gounni AS, Aldebert D, Delaporte E, Prin L, Capron A, Capron M 1996. Synthesis of type 1 (IFN $\gamma$ ) and type 2 (IL-4, IL-5, and IL-10) cytokines by human eosinophils. Ann NY Acad Sci 796: 203208.

Levi-Schaffer F, Lacy P, Severs NJ, Newman TM, North J, Gmperts B, Kay AB, Moqbel R 1995. Association of granulocyte/macrophage colony-stimulating factor with the crystalloid granule of human eosinophils. Blood 85: 2579-2586.

Levi-Schaffer F, Barkans J, Newman TM, Sun Ying, Wakelin M, Hohenstein R, Barak V, Lacy P, Kay AB, Moqbel R 1996. Identification of interleukin-2 in human peripheral blood eosinophils. Immunology 8: 155-161.

Lim KG, Wan HC, Bozza PT, Resnick MB, Wong DT, Cruikshank WW, Kornfeld H, Center DM, Weller PF 1996. Human eosinophils elaborate the lymphocyte chemoattractants: IL-16 (lymphocyte chemoattractant factor) and RANTES. J Immunol 156: 2566-2570.

Melani C, Mattia GF, Silvani A, Care A, Rivoltini L, Parmiani C, Colombo MP 1993. Interleukin-6 expression in human neutrophil and eosinophil peripheral blood granulocytes. Blood 81: 2744-2749.

Miyamasu M, Hirai K, Takahashi Y, Iida M, Yamaguchi M, Koshino T, Takaishi T, Morita Y, Ohta K, Kasahara T 1995. Chemotactic agonists induce cytokine generation in eosinophils. J Immunol 154: 1339-1349.

Möller GM, de Jong TA, van der Kwast TH, Overbeek SE, Wierenga-Wolf AF, Thepen T, Hoogsteden HC 1996a. Immunolocalization of interleukin-4 in eosinophils in the bronchial mucosa of atopic asthmatics. Am J Respir Cell Mol Biol 14: 439-443.

Möller GM, de Jong TA, Overbeek SE, van der Kwast TH, Postma DS, and Hoogsteden HC 1996b. Ultrastructure immunogold localization of interleukin-5 to the crystalloid core compartment of eosinophil secondary granules in patients with atopic asthma. J Histochem Cytochem 44: 67-69.

Moqbel R, Hamid Q, Ying S, Barkans J, Hartnell A, Tsicopoulos A, Wardlaw AJ, Kay AB 1991. Expression of mRNA and immunoreactivity for the granulocyte/macrophage-colony stimulating factor (GMCSF) in activated human eosinophils. J Exp Med 174: 749-752.

Moqbel R, Ying S, Barkans J, Newman TM, Kimmitt P, Wakelin M, Taborda-Barata L, Meng Q, Corrigan CJ, Durham SR, Kay AB 1995. Identification of mRNA for interleukin-4 in human eosinophils with granule localization and release of the translated product. J Immunol 155: 4939-4947.

Mosmann TR, Coffman RL 1989. TH1 and TH2 cells: different patterns of lymphokine secretion lead to different functional properties. Ann Rev Immunol 7: 145-173.

Nakajima H, Gleich GJ, Kita H 1996. Constitutive production of IL-4 and IL-10 and stimulated production of IL- 8 by normal peripheral blood eosinophils. J Immuno1 156: 4859-4866.

Nonaka M, Nonaka R, Woolley K, Adelroth E, Miura K, Okhawara Y, Glibetic M, Nakano K, O'Byrne P, Dolovich J, Jordana M 1995. Distinct immunohistochemical localization of IL-4 in human inflamed airway tissues. IL-4 is localized to eosinophils in vivo and is released by peripheral blood eosinophils. J Immunol 155: 3234-3244.

Ohkawara Y, Lim KG, Xing Z, Glibetic M, Nakano K, Dolovich J, Croituru K, Weller PF, Jordana M 1996. CD40 expression by human peripheral blood eosinophils. J Clin Invest 97: 1761-1766.

Ohno I, Lea R, Finotto S, Marshall J, Denburg J, Dolovich J, Gauldie J, Jordana M 1991. Granulocyte/macrophage colony-stimulating factor (GM$\mathrm{CSF}$ ) gene expression by eosinophils in nasal polyposis. Am J Respir Cell Mol Biol 5: 505-510.

Ohno I, Lea RG, Flanders KC, Clark DA, Banwatt D, Dolovich J, Denburg J, Harley CB, Gauldie J, Jordana M 1992. Eosinophils in chronically inflamed human upper airway tissues express transforming growth factor $\beta 1$ gene (TGF $\beta 1)$. J Clin Invest 89: 1662-1668.

Ohno I, Nitta Y, Yamauchi K, Hoshi H, Honma M, Woolley K, O’Byrne P, Dolovich J, Jordana M, Tamura G, Tanno Y, Shirato K 1995. Eosinophils as a potential source of platelet-derived growth factor B-chain (PDGF-B) in nasal polyposis and bronchial asthma. Am J Respir Cell Mol Biol 13: 639-647.

Ohno I, Nitta Y, Yamauchi K, Hoshi H, Honma M, Woolley K, O’Byrne P, Tamura G, Jordana M, Shirato K 1996. Transforming growth factor- $\beta 1$ (TGF $\beta 1$ ) gene expression by eosinophils in asthmatic airway inflammation. Am J Respir Cell Mol Biol 15: 404-409.

Powell PP, Klagsbrun M, Abraham JA, Jones RC 1993. Eosinophils expressing heparin-binding EGF-like growth factor mRNA localize around lung microvessels in pulmonary hypertension. Am J Pathol 143: 784-793.

Rand TH, Silberstein DS, Kornfeld H, Well PF 1991. 
Human eosinophils express functional IL-2 receptors. J Clin Invest 88: 825-832.

Sabin EA, Kopf, MA, Pearce EJ 1996. Schistosoma mansoni egg-induced early IL-4 production is dependent upon IL-5 and eosinophils. J Exp Med 184: 1871-1878.

Schall TJ, Bacon K, Toy KJ, Goeddel DV 1990. Selective attraction of monocytes and T lymphocytes of the memory phenotype by cytokine RANTES. $\mathrm{Na}$ ture 347: 669-671.

Takanaski S, Nonaka R, Xing Z, O’Byrne P, Dolovich J, Jordana M 1994. Interleukin 10 inhibits lipopolysaccharide-induced survival and cytokine production by human eosinophils. J Exp Med 180: 711-715.

Tan X, Hsueh W, Gonzalez-Crussi F 1993. Cellular localization of tumor necrosis factor (TNF)- $\alpha$ transcripts in normal bowel and in necrotizing enterocolitis. TNF gene expression by Paneth cells, intestinal eosinophils, and macrophages. Am J Path 142: 1858-1865.

Taub D, Dastych J, Inamura N, Upton J, Kelvin D, Metcalfe D, Oppenheim J 1995. Bone marrow-derived murine mast cells migrate, but do not degranulate, in response to chemokines. J Immunol 154: 2393-2402.
Weller PF, Rand TH, Barrett T, Elovic A, Wong DT, Finberg RW 1993. Accessory cell function of human eosinophils: HLA-DR-dependent, MHC-restriction antigen presentation and interleukin- $1 \alpha$ formation. J Immunol 150: 2554-2562.

Wong DT, Weller PF, Galli SJ, Elovic A, Rand TH, Gallagher GT, Chiang T, Chou MY, Matossian K, McBride J, Todd R 1990. Human eosinophils express transforming growth factor $\alpha$. J Exp Med 172: 673-681.

Wong DT, Elovic A, Matossian K, Nagura N, McBride J, Chou MY, Gordon JR, Rand TH, Galli SJ, Weller PF 1991. Eosinophils from patients with blood eosinophilia express transforming factor $\beta_{1}$. Blood 78: 2702-2707.

Ying S, Meng Q, Taborda-Barata L, Corrigan CJ, Barkans J, Assoufi B, Moqbel R, Durham SR, Kay AB 1996. Human eosinophils express mRNA encoding RANTES and store and release biologically active RANTES protein. Eur J Immunol 26: 70-76. Yousefi S, Hemmann S, Weber M, Holzer C, Hartung K, Blaser K, Simon HU 1995. IL-8 is expressed by human peripheral blood eosinophils. Evidence for increased secretion in asthma. J Immunol 154: 54815490. 